\title{
The Role of Petronage in the Existence of the Temple of Ganjuiran
}

\section{Danang Bramasti}

Composition and Research Program Graduate School of Indonesia Institute of the Arts Yogyakarta, 2015, email: bramasti@jesuits.net

\begin{abstract}
Ganjuran temple is a place of Catholic worship located in Yogyakarta. The temple had been built by Schmutzer family, a Dutch sugar mill owner, from 1927 until 1930 in the shape of a Hindu temple. However, after the temple was erected, it did not get the attention of Catholics that it was dirty. Finally it was neglected and became a playground for children. It was only in 1990, Father Tomo made the temple a pilgrimage site by creating a series of activities centered on the temple. This paper is dedicated to study the role of patron, the Schmutzers and Father Tomo in the existence of the Temple of Ganjuran in three steps. Firstly, it strives to explain why this Catholic place of worship was built in the shape of a Hindu temple. Secondly, it explains the social process by which the temple then had been forgotten for sixty years. Thirdly, it explains the social process by which the temple became a major Catholic pilgrimage site in Indonesia. This study utilizes the concept of patronage in the development of an artwork as the main framework (Becker, 2008). The methods of applied study are by examining documents, interviews with people involved with the temple and field observations. By treating Ganjuran temple as an artwork embedded in an 'art world', web of actors who contributed to the making of Ganjuran temple as a locus of religius and artistic action is made visible.
\end{abstract}

Keywords: Ganjuran temple, art world, social process, patronage

\section{INTRODUCTION}

Think of all the activities that must be carried out for any work of art to appear as it finally does (Becker, 2008:3).

Ganjuran temple was the last building of a series of buildings built by the brothers Julius and Josef Schmutzer in Ganjuran, a location south of Yogyakarta in the island of Java. The construction had been lasting from 1927 to 1930. The Schmutzers built it as a personal place of worship behind the Ganjuran Catholic Church as an offering of gratitude that their enterprise had succesfully avoided bankruptcy and of celebration of the 10th wedding anniversary of Julius and Caroline Schmutzer. In addition, it was also a day of farewell with Josef Schmutzer who was returning to the Netherlands to teach in Delft University (Helling SJ, 1930: 129).

The Schmutzers owned a sugar mill and plantation called Gondang Lipuro which survived the wave of sugar factory worker strikes in Java in 1920 (Sulistyo, 1995: 125). The Schmutzers' treatment to their workers was striking. They respected their dignity by providing decent wages to meet their real needs (Elihami, 1995: 42). The Dutch catholic family was influenced by Encyclical Rerum Novarum of Pope Leo XIII 
emphasizing the dignity of workers (Rerum Novarum, 1890: point 22). The Schmutzers had been trying to improve the welfare of workers by setting up schools, clinics, and orphanages (Dewan Paroki, 2004: 28).

In 1934, Julius Schmutzer who used to pray by the temple everyday had to return to the Netherlands with his wife Caroline due to an illness. In effect the temple was neglected and lost its religious significance ${ }^{1}$.

After being abandoned for more than 60 years, the temple's faith was to change when in 1988, Father Gregorius Utomo Pr (Father Tomo), a local diocesan priest took the lead of the parish. He then revived the idea behind the establishment of the Temple Ganjuran, i.e partiality to the poor and sorrowful by inviting people to make concrete actions towards change and gave special attention to the poor and oppressed: farmers, workers, fishermen, and so on (Dewan Paroki, 2004: 38-39).

In 1990, Father Tomo formed Farmers and Fishermen Association World Food Day to combat the environmentally damaging green revolution as well as empowerment of small farmers and landless farmworkers. The event also launched the Declaration of Ganjuran (Dewan Paroki, 2004: 40) which

...invites members of the society to build a sustainable agriculture and rural areas, by practicing sustainable rural and agriculture development which are ecologically sound, economically feasible, culturally adapted, and socially just. (http://greenorganic- rice.blogspot.com/2008/08/ sekretariat pelayanan tani dan nelayan, 25 June 2015, 16:39)

Father Tomo's movement started with activities centered on the temple. This temple later was becoming rose to fame and by 1997 pilgrims flocked from different parts of Indonesia. It is estimated that the Javanese Mass on First Friday of every month most be attended by 3000 - 5000 pilgrims (Ganjuran Parish Record, 2015). From a disenchanted and neglected site, now the temple has regained its sacred aura. People do not dare to tinker around the temple, even a lot of them bow when passing in front of the temple.

\section{MATERIALS AND METHODS}

This paper is dedicated to study, in Aristotelian language, the role of patronage of the Schmutzers and Father Tomo in the existence of the Temple of Ganjuran. Firstly, it strives to explain why this Catholic place of worship was built in the shape of a Hindu temple. Secondly, it explains the social process by which the temple had been then forgotten for sixty years. Thirdly, it explains the social process by which the temple became a major Catholic pilgrimage site in Indonesia. In order to carry out the aforementioned tasks, this paper seeks to answer the following questions:

1 A resource person (graduate level educated) interviewed in May 2015 about his perception of the temple before Father Tomo's intervention:

Saya tidak menyadari bahwa candi dapat menjadi tempat berdoa. Kalau mau beribadat ya harus di gereja. Candi hanya sekedar monumen yang tidak sakral. Candi itu hanya tempat bermain (I didn't realize that the temple could be a place for prayer. If you wanted to pray, you had to go to the church. The temple was only a non-sacred monument. The temple was just a play ground (for children-researcher interpretation) (Janu, 26 years old). 
What is the role of Josef and Julius Schmutzer as patrons in the existence of the temple of Ganjuran?

Why did they build the Hindu temple for Catholics to pray?

What is the role of Father Tomo as patron in the existence of the temple of Ganjuran?

Why can he make the Hindu temple as a place of prayer for Catholics?

This study utilizes the concept of patronage in the development of an artwork as the main framework (Becker, 2008). It also utilizes the concept of convention and distribution that is used by patrons to analysis the development of the Ganjuran temple.

The methods of applied study are by examining documents, interviewing people involved with the temple and field observations. By treating Ganjuran temple as an artwork embedded in an 'art world', web of actors who contributed to the making of Ganjuran temple as a locus of religius and artistic action is made visible. These actors produced ideas, put the ideas into a form of a physical artwork, used and experienced the artwork, and even trained people how to use and how to experience it. Ideas from Josef Schmutzer were executed by Ito (carver), and sixty years later, Father Tomo recasted the temple as a pilgrimage site, trained the people of Ganjuran how to use the temple of Ganjuran and experience it using Javanese cultural expressions without any conflict with the bible. ${ }^{2}$

This study argues that as social actors in the world of Ganjuran temple, Joseph Schmutzer and Father Tomo acted specifically as patrons (Becker, 2008). Following Becker's further study, this paper argues that the role of patrons in an artworld can be understood from two distinct frameworks, namely upstream and downstream (Becker, 2013). The upstream framework looks at the initial process that contributes to the final artwork, whereas the downstream framework follows what happens next after a work of art is finished. It is possible that a work of art initiated in an early patronage system is forgotten or neglected after it is finished, because there is no continuing patronage that supports its existence. And then, some years later, a new patron may rediscover the work of art and gets it "born again".

\section{The Patronage}

This section describes the position of the Schmutzers and Father Tomo as patrons and the existence of the Temple Ganjuran. Therefore, it will be explained first about the meaning of existence and then about patronage.

2 In catholic literatures, conflict between the bible and local norms and values is one fo the characters that define the dynamics between universal and local church. Further reference on this can be found in Hadrianus Tedjoworo, OSC work where he stated that the content of the teachings of the Catholic faith on the Javanese church can be developed so that they can also build a better relationship with the local cultural backgrounds and it doesn't conflict with the bible. However, his basic study was about the parable that fit to the local culture and dosen't have any conflict with the bible. Keluarga gerejani, an ecclesial family: A catechetical exploration of church-images among Catholics in Java, 2013, Radboud University, Nijmegen, Holland. A different take on the subject from the perspective of studies of Art was from Sumandiyo Hadi who did research on art in religious rituals. His study revealed that rituals are simultaneously an experience of faith and art without any inherent conflict. The presence of expressive symbols or art in religious rituals enrich the beauty of the liturgy as a pilgrimage. (Hadi, Sumandiyo. Seni dalam Ritual Agama, 2006, Universitas Airlangga, Surabaya). 
According to Becker,

...the patronage system, some people or organizations supporting the artist as a whole during the period of the contract to make a particular work, or maybe even just for a few specific works. People who can support artists in this way, comes from the wealthy and privileged class in society (Becker, 2008, 99).

\section{Josef and Julius Schmutzer as Patrons}

This explanation shows how their respective roles to the existence of the Temple Ganjuran. Explanation of existence, according to Aristotle, is the existence of something needs causes. According to Aristotle there are four causes of existence: causa material, causa formal, causa efficient and causa final. We must take account of what he says about causes. There are, according to him, four kinds of causes, which were called, respectively, material, formal, efficient, and final. Let us take an example the man who is making a statue. The material cause of the statue is the marble, the formal cause is the essence of the statue to be produced, the efficient cause is the contact of the chisel with the marble, and the final cause is the end that the sculptor has in view (Russel, 2004:203).

In cases of the temple Ganjuran can be explained as follows: Causa material is granite and the white karst materials from temples and statues contained therein. Formal causa is the stone which later became the form of temples and statues. Causa efficient is who makes the rock into a temple and statues. Causa final is the final idea of the temple and the statue was made.

The Schmutzers's role in the existence of the temple is as causa efficient and causa final because they are the ones who made the temple. Josef Schmutzer is not however a sculptor but he made the design of the temple and statues and then sent them to a sculptor named Ito to make it happen.

After the Schmutzers had left Ganjuran, the Temple of Ganjuran was neglected and rarely used as a place of prayer. The temple is only used once a year at a celebration called the procession. The temple is still there but its presence is not as initiated by the Schmutzers as a place of prayer. Father Tomo's role in the existence of the temple is as causa final because he carried out the final idea of the Schmutzers to the temple as a place of prayer.

Josef and Julius Schmutzer were wealthy and privilage class in society. The Schmutzers built a sugar factory in Ganjuran, named Gondang Lipuro in 1912. (Elihami, 1995: 30). In 1919, Josef Schmutzer married Lucie Amelie and had got three children of this family living in Ganjuran until 1920. In the period of 1918-1919 Josef had been pointed a vice chairman of the People's Council therefore they moved to Bogor. In 1929, Josef Schmutzer confirmed as a professor at the University of Delft and in that year they left Ganjuran to return to the Netherlands (Elihami, 1995: 34).

Meanwhile Josef's brother namely Julius Schmutzer, in 1920 married Caroline van Rijckervorsel and since then they had been living in Ganjuran to manage a sugar 
factory Gondang Lipuro. The family was very keen to practise the social teachings of the church. Julius was instrumental in the spread of Catholic missions in Central Java, especially Ganjuran. Of his services for the church then in 1930 Pope Pius XI conferred the honor of Julius "Pro Ecclesia et Pontifice" and he was named a "Knight of the Order of Saint Gregory the Great". Meanwhile, the Kingdom of the Netherlands gave Caroline the title of "Knight of the Order of Oranje Nassau" over all her social work (Elihami, 1995: 36-37).

Josef and Julius were touched by the Encyclical Rerum Novarum, a teaching of the Catholic Church, published by Leo XIII in 1891, of the Social Doctrine of the Church concerning capital and labor. It teaches that workers must be respected in accordance with the dignity of being. (Elihami, 1995: 42). Schmutzer brothers were also affected by the Ethical Policy, announced in 1901, by Queen Wilhelmina. Ethical Policy was a thought that the colonial government holds the moral responsibility for the welfare of the natives. This moral movement had affected Julius and Josef Schmutzer (Elihami, 1995: 41).

The Schmutzers saw that the Javanese, particularly in Ganjuran, had been brutally occupied for many years by the colonial rulers.The condition of the people were not only very poor but also underdeveloped. They were malnourished, sickly,even they were uneducated. The first thing done by the Schmutzers in response to that situation is to meet the primary needs of the people. The Schmutzer provided the poor with financial aid. In 1917, in addition to handing out money, the Schmutzers bought rice from Saigon and then sold cheaply to the people of Ganjuran. (Elihami, 1995: 43-44). In 1924, they even built an irrigation channel to help farmers.

Other social work carried out by family Schmutzer in Ganjuran was the establishment of schools, clinics, and orphanages. The schools were founded by the Schmutzers in 1910-1930 in the area around the sugar factory Gondang Lipuro, Ganjuran. An education system that is used in schools, in addition to the Western method, also used the local culture. This system retained the joints of Javanese culture, for example in terms of dress, language, logic, reading material, writing and arithmetic, which the teaching conducted by indigenous teachers from Ganjuran and Muntilan (Soekiman, 2000: 77).

\section{DISCUSSION}

\section{Why in the Shape of a Temple}

In the 1920s, a lot of movement led to the appreciation of the local culture and high spirit of independence, especially in colonies such as in Java. The movement that was related to the Catholic Church is an international exhibition of the Catholic mission held in the Vatican in 1925. Catholic Mission in Java, had been sending many of the artifacts in the form of artistic handicrafts. These events affected the Schmutzers to initiate movement with a mission based on the local culture (Aritonang and Steenbrink, 2008: 926). 
The Schmutzers realized that in schools, the Javanese children received the lessons of both science and religion from the West, though they grew up and lived in the midst of its own culture of their ancestors. The Schmutzers had hoped that the art of ancient Java, with the Christian spirit, could lead them to a new life that was developing the teaching of Christianity in Javanese culture (Soekiman, 2000: 114).

Based on these ideas, on April 16 $6^{\text {th }}, 1924$ the Schmutzers began to build a church and then it was blessed by Mgr. A van Vellsen, Vicar Apostolic of Batavia on August $20^{\text {th }}$, 1924. The location was close to the buildings of hospitals, schools and orphanages that had been constructed previously (Elihami, 1995: 55). Inside the church there is altar with Javanese style.

The Schmutzers seemed not satisfied that the Javanese style was only on the interior. They wanted the whole building featuring shades of Java. In 1927 they started to build a place of worship of the Catholic entirely in the shape of a Javanese Hindu temple. The temple is slim, in general by 9 meters high, built above the cornerstone with a size of $5 \times 14$ meters and made of black andesite stone taken from Mount Merapi on the northern city of Yogyakarta so that the temple is black with a rough surface.

This building can be regarded as a Hindu temple for having such criteria, it has three parts (Sumintardja, 1981: 88-89): Firstly, the base of the temple is called Bhurloka. In this section there is a ladder into the middle part of the temple. On either side of the entrance stairs, usually decorated with carvings of makara but on this temple there is no carving. Similarly, in the foot wall of the temple which is usually decorated with flora and fauna, or in certain temples decorated with the figure of a guard as Dwarapala but this temple is plain.

At the center of the base of the temple, just below the main room there is usually a well containing pripih (stone coffin). In this pripih usually is contained the ashes of the king and the relics of holy objects such as gold sheets inscribed with spells, ancient coins, gems, glass, pieces of gold, silver sheet, and shells. In this temple, it was planted a statue of Jesus with a height of 75 centimeters, and the brass plate on which the founding history of the temple is written.

Secondly, called the body of the temple. It is a central part of the temple, a room, which is regarded as a transitional world or bhuwarloka, which depicts a world where the holy man seeks to attain enlightenment and inner perfection. At this temple, the room contains a $1.5 \mathrm{~m}$ height statue of Jesus called the Sacred Heart of Jesus which indicates that the statue is the main statue worshiped. On top of it there is an inscription in Javanese language which reads: His Majesty the King Jesus Christ Patron of the Nation. The statue is made of white karstic rock that is hard but smooth in surface.

The statue of Jesus depicts a king-priest in the world of puppetry, which is wearing a javanese king's crown and robe. On footwear there is a lotus that is the hallmark of a statue of Buddha. The backrest throne of the statue was resembling a petal of lotus. It is like the throne of the statue of Buddha in general. Buddhist elements which also appear strong is the footstool of the statue that is shaped a lotus. Robe at the statue, 
which is half open, made to resemble the robes of the Buddha that is half open. At this statue there are many ornaments that show its image as a king who at once became a priest.

Thirdly, is the top of the temple that has become a symbol the world over or swarloka, which depict the heavenly realm of the gods and the souls who have achieved perfection residing. In general, the roof of the temple consists of three levels which are increasingly smaller and smaller from the bottom of the roof. At the top level of the temple, there is a false phallus with relief cross.

What distinguishes it from other Hindu temples is the presence of cross form of relief on the phallus at the top level of this temple. The biggest difference of this temple from other Hindu temples is a statue contained in this temple. The statue's right hand points at his chest. Engraved on his chest is shining heart. In the tradition of the Catholic Church, the type of statues or images of men whose hands points at his chest, with shining heart, is called the Sacred Heart of Jesus. It was seen on a statue of Jesus from France made in 1920. Based on the statue from French, it can be concluded that the statue contained in Ganjuran temple is a statue of the Sacred Heart of Jesus.

The Schmutzers chose to build the Catholic's place of worship in the shape of a Hindu temple because they knew that Javanese is very familiar with the Hindu culture, such as the story of Mahabharata or Ramayana. They succeeded in bringing Christianity in Javanese culture.

The temple actually was originally intended to be a family monument but when it was inaugurated by the church officials, it was said as a national monument (Helling,1930:129). The expression 'national' was a brave statment at the time because the Dutch colonization was still very strong in Indonesia. This statement was stated in front of 2000 attendees from Batavia, Semarang, Solo, Magelang, Yogyakarta, and Salatiga (Helling, 1930: 132).

\section{Father Tomo as a Patron}

Father Tomo's role in social work that stands out is in the field of agriculture. He was born in Ganjuran on Feburary 17th, 1929 with the full name Raden Gregorius Utomo. Karsopoernomo, his grandfather, was working as a clerk in a family-owned factory Gondang Lipuro belonging to the Schmutzers (Teiseran, 2013: 19).

At the age of 6 he moved to Rejoso Klaten. In this new place he studied about Javanese tradition that later greatly influenced the course of his life. His views on environmentfriendly, farmer and agriculture, and food self-sufficiency are strongly influenced by his experience in Rejoso (Teiseran, 2013: 27).

Father Tomo said, "I learned the traditions of Java in Rejoso, namely the experience of hanging out with the village children, attended the ceremony before the harvest, called Wiwit, familiar with terms such as "Dewi Sri" (Godess of Rice), Sadranan in Ruwah and so on. I learned so much before my school of Javanese tradition in Ganjuran. Childhood experiences in Rejoso, have reinforced my views about how we should

3 Sadranan: making offering for ancestors spirits in the tomb during 8th month (ruwah) 
maintain self-sufficiency and protect the farmers, so that the World Food Day October 16th, 1990, ASEAN Farmer Seminar was held at Ganjuran. as the result, it produced Ganjuran Declaration."(Teiseran, 2013: 28).

In 1946, the capital city of the Republic of Indonesia moved to Yogyakarta as Jakarta, Bogor, and Bandung were controlled by the Allies and the Netherlands. Some schools were also moved to Yogyakarta including Bogor Agricultural School which was moved to Wedi, Klaten. Father Tomo then studied agricultural in that place (Teiseran, 2013: 59).

In 1951, Tomo, who worked at the Department of Agriculture in Jakarta, was sent to the USA to pursue education in Agricultural Extension Work College of Agriculture, Cornell University, New York to study agriculture. After completion of studies in the USA, he returned to work at the Ministry of Agriculture and to implement the Plan of Kasimo which essentially is self-sufficiency and rural community education (Teiseran, 2013: 60).

When he returned to Indonesia, he decided to enter the seminary of Mertoyudan in 1954. In 1963 he was ordained priest. His first assignment was as a parish priest in Klaten whose territory includes the villages around Mount Merapi. His educational background led him to acomplish tasks relating social work. In 1969 he was appointed Delegatus Social (Social Delegate) Indonesian Bishops' Conference whose task was to organize social movements. One concern at the moment was the uneven development. In 1970, Carri SJ made the idea to create a movement called Fasting Action

Development (APP). According to Carri SJ, Catholics need to run the Action Fasting for bridging the gap between rich and poor. This movement was carried out by Father Tomo, as Social Delegatus, at any period of fasting before Easter. This movement is still taking place throughout Indonesia until now (http://sejarahapp.blogspot.com/3 sept. 2015, h. 12.43).

In 1982 to 1984 he had been appointed director of the Institute for Development and Social Research, Indonesian Bishops Conference. Then in 1985-1986 he returned to the USA to study in Ecological Agriculture College of Agriculture, Santa Cruz University, California, USA. He was then still serving in New York until 1988 and after that he returned to Indonesia to deidcated at Ganjuran, Yogyakarta.

When he came back to Ganjuran as a priest, he was known as a highly educated and fluent in social areas and agriculture. Especially, he is fluent in Javanese culture. Furtehermore, being highborn he is also highly regarded. He serves as a patron for Catholics in Ganjuran.

Father Tomo's role in the existence of the Temple of Ganjuran can be explained in two ways. The first social movement and the second religious movement associated with Javanese culture. Father Tomo's movement is closely related to what has been done by the Schmutzers. Father Tomo actually continued the spirit built by the Schmutzers in different social context and era. 
Besides the Declaration of Ganjuran in 1990, one of the prominent movements is the movement of the Apostleship of Prayer. People who wanted to be prayed, sent their prayer to Father Tomo. In 1997, a lot of people were not satisfied just to send a letter to him so that they came directly to Ganjuran. They not only just came to chruch but also sat in front of the temple to pray there. Ever since the temple has transformed into a place of pilgrimage (Dewan Paroki, 2004). They do it because Father Tomo, with Javanese attribute, prays in front of the temple as their model.

Undoubtedly, the process showed agreement in the way of praying in front of the temple. All ceremonies are performed in the nuances of Java. This deal makes Catholics more confident to pray using the Javanese style. So although the nuance of Ganjuran temple is Hindu-Buddhist, they are no longer afraid to come there because the church authorities both support and even encourage people to pray in such a Javanese style.

As a result, people are no longer afraid to proclaim the miracle they received because of prayer in front of the temple. Even the church took over this miracle as a result of a Catholic prayer with the nuances of Java. The story of this miracle is also an attraction for pilgrims to pray in front of the temple.

In 2006, unfortunately a voilent earthquake destroyed the church. Father Tomo decided to create a new church with a Javanese pattern that couldn't be implemented by the Schmutzers because of Vatican's ban. Javanese pattern that is used by Father Tomo is "nothing to do with politics" but indeed purely local cultural influences.

Obviously, the idea of Father Tomo to rebuild the church of Ganjuran that was destroyed by the earthquake is revealed from interviews with him, as follows:

The church in Jerusalem was built by the Jewish style, the church evolved into Asia turned to be a Greek church, and then evolved into a church in Rome with European style, but when it goes to Java, why it keeps the European style. Well, this is not suitable. In Java it should be Javanese style.

\section{Convention and Distribution of Art}

The next discussion is about convention and distribution of art that is related to the existence of the temple of Ganjuran. In the convention discussion, it studies about how the patrons build a habit to pray in front of the temple. And in the distribution discussion, it studies about how the convention was distributed to the public.

Sometimes people ask how to understand a work of art, for example, about western music. How people can understand the notation song. In the world of Western music, for example, people know that after C-D, it will appear E which means the do-re-me. Or after C-E, it will appear $\mathrm{G}$ meaning do-me-sol. This pattern has been taught in schools even since childhood. That is convention. We can answer the question, then, because we learned the materials needed to solve the problem years ago (Becker, 2008:41). Becker explained further that:

Conventions known to all well-socialized members of a society make possible some of the most basic and important forms of cooperation characteristic of an art world (Becker, 2008:46). 
However, the convention will not develop properly unless it is developed. According to Becker:

Fully developed art worlds, however, provide distribution systems which integrate artists into their society's economy, bringing art works to publics which appreciate them and will pay enough so that the work can proceed.(Becker, 2008:93).

The development of Ganjuran temple depends on how the convention is built and then distributed to the general public by the patrons, The Schmutzers and Father Tomo.

\section{It Was Built and Forgotten}

After the temple was bulit, the Schmutzers did not make any activities associated to the existence of the temple. In the upstream-downstream analysis by Becker, it shows that the role of the Schmutzers as patrons was only in the upstream process which is only in the process of making the temple. In the downstream process, they did not make any process after the temple was formed. It means that they didn't distribute or promote the temple to public.

Why The Schmutzers did not make any downstream process? The temple that was built behind the church became the private monument for the Schmutzers. The Schmutzers did not intend to put the temple as a place of public prayer. It is seen from the habit of Julius Schmutzer who always prayed in front of the temple before going to work. It is told by Astokodatu (74), elder Catholics of Ganjuran, as follows:

"The temple is not placed in front of the church even in the back. It is located directly in front of the Schmtzers' house. There were lights in the temple that the switch is in the Julius Schmutzer's house. This is a sign that the temple is a monument to the family as gratitude for the success of the sugar factory "(Astokodatu, 13-05-2015)

When the Schmutzer went back to the Netherlands in 1934, the Catholics in Ganjuran did not have sense of belonging to the temple. As a result, they did not take care of the temple and it became neglected. Nobody knew how to pray in front of the temple. In that condition, the temple, slowly but surely, became unknown.

In the analysis of Art World, the Schmutzers did not make a convention about how to pray in front of the temple to the Catholics in Ganjuran. In the absence of convention, the temple was neglected by the Catholics of Ganjuran. As a result, the temple was not distributed to the public as well. The neglected art work will not be published and the unpublished art work will be more unknown (Becker, 2008:95). The temple entered the phase of unknown for sixty years. For sixty years, the temple was not a place of prayer for Catholics and just being a playground for children.

During that phase, the temple became unsacred. It was revealed from an interview with a Catholic from Ganjuran, who said:

One day we cycled around the temple (note: when they were kids). Then we remembered a story of old people that in this temple there are treasures. Then we remove the mudguard bike, and we made it as a tool for prying the stone temple. We hoped that we found a treasure under the stone temple. (Indra, 08-5-2015). 
The temple was not only become unsacred but also became an embarrassing place to pray. About this situation, Hendri (28), said:

I was ashamed to pray in front of the temple because nobody prayed there. As Catholics, if you want to pray, you have to go to church and not to the temple. People preferred to picnic or play in front of the temple rather than to pray. For me it was a playground for very strong winds from the south making it suitable for playing kites. I was not even afraid to climb up the temple, though there is a statue of Jesus, I did not care. (Hendri, 08-5-2015).

Besides, the temple at that time was also a place where people socialized. There were mothers who cared for their children in the courtyard of the temple or children gathered around the temple after the completion of the mass for a play or relax and having meal together.

Things that make this situation even worse are that the programs created by the sexton never put the temple as the center of activities. Routine activities such as the maintenance of temples, gardens and lights around the temple were never done by the sexton of Ganjuran. The temple became dirty and mossy, dark and spooky. In the afternoon, the situation around the temple was so quite that there were no many people dare to come to that place. At night, the atmosphere of the temple was very dark because there were no adequate lights. This situation raised many spooky stories. It causes people not moved to pray in front of the temple so that its presence is neglected.

The temple, besides neglected, lost its sacredness because no one prayed in front of the temple. Hendri (28) told as follows:

Before the temple was famous, I rarely see anyone prayed in front of the temple. The statue was unpainted and the temple was mossy. The impression of this temple was creepy. After four in the afternoon, I would never dare to play at the temple. (Hendri, 08-5-2015).

Related to the analysis from Becker about convention, for Catholics in Ganjuran at that moment, the most obvious was lack of convention on how Catholics pray in front of a Catholic worship place in the form of a Hindu temple properly. The shape of the Hindu temple for Catholic worship is not normal because it does not comply with the agreement at the time that the Catholic places of worship must be in the Western nuanced. Catholics are afraid to pray in front of a place of worship that was considered abnormal. The biggest fear is that they would be considered heresy.

\section{RESULTS}

\section{Building an Art World}

All artistic work, like all human activity, involves the joint activity of a number, often a large number, of people. The work always shows signs of joint activity. About Art World, Becker said:

The forms of activities may be ephemeral, but often become more or less routine, producing patterns of collective activity we can call an art world (Becker, 2008:1). 
As a patron, Father Tomo put the temple as a centre of an art world that directs all the activities there to support the existence of the temple.

In order to establish the temple of Ganjuran as a prayer center for the people, Father Tomo makes a series of events and physical improvements. The temple should be easily visible, it is necessary to find ways in which the temple is easily seen by the people who came (Dewan Paroki Gereja Hati Kudus Tuhan Yesus Ganjuran, 2004: 51). In 1995, the Parish Council of Ganjuran started to improve the Temple. The corner of the church and the place around the temple, that were dirty and neglected, were cleaned and repaired. The grass around the temple was cut and the soil was covered by stones or asphalt (Dewan Paroki Gereja Hati Kudus Tuhan Yesus Ganjuran, 2004:55).

In addition, in 1997 to 1998, the Parish Council of Ganjuran continued the plan of the Schmutzers to build a series of the station of the cross around the temple. In 1927, the Schmutzers had designed the station of the cross but they didn't have permit from Vatican to build it. The construction can be completed within a year by a sculptor named Nyoman who lived in Muntilan, near Ganjuran.

In 2000, the temple of Ganjuran was established as one the places of pilgrimage for Catholic in Archdiocese of Semarang and the place called Mandala Hati Kudus Yesus (The Site of The Sacred Heart of Jesus). In response to it, since 2000 to 2004 the Parish Council of Ganjuran fixed organizational and physical infrastructure. The physical infrastructures fixed were constructing parking area, pendapa, and toilet. Outside the fence of the Site, the Council built a place for small traders. (Dewan Paroki Hati Kudus Tuhan Yesus Ganjuran, 2004, 56-70). In 2006 there was a violent earth quake that totally destroyed the church. The new church built in Javanese nuance. Since that time the site became a place with a thick Javanese nuance.

The ceremonies which are centered on the temple are always in the shades of Java. The biggest ceremony is called Procession that is held annually in June. Procession is a Eucharist that is held before the temple and usually attended by more than 4000 people. All the church officers, including priests, are dressed in Javanese style, whereas songs are sung in the Javanese language using not only the musical accompaniment of classical Javanese orchestra, mentioned gamelan, but also Javanese dances. In this ceremony, there are also many fruits and vegetables that are arranged to resemble a mountain entitled gunungan which is a native Javanese tradition.

In Javanese tradition, gunungan is a model of mountain made of sticky rice, sweets, various foods, crackers, fruits and vegetables. The gunungan will be carried in procession to celebrate the birthday of Prophet Mohammad. After the prayer, the Gunungan that symbolizes the wealth and prosperity of Mataram Sultanate will be picked, fought over and ripped apart by the people that have already been waiting in the square, as they believe these objects are sacred, potent and are able to bring good luck, prosperity and wealth upon their households. 
Usually these parts of Gunungan will be either kept in the house for luck or buried in the rice fields as the traditional Javanese farmers believe that these objects will grant their fields' fertility and protection from locust, plagues, and any misfortunes that might befall them. (kebudayaanindonesia.net, 06-02-2016)

Furthermore, there are some celebrations that use Javanese attribute, namely the first Friday night and Nyadran. The Friday night is started in the Thursday night before the temple. It is started at $6 \mathrm{pm}$ by reading a prayer of petitions at first than continued by Eucharist and ended by making procession in which they pray while walking around the temple. Nyadran is a series of culture in the form of cleaning ancestral graves, sowing flowers, and the main event is having meal together at the tombs of their ancestors (kebudayaanindonesia.net, 06-02-2016).

What was done by Father Tomo has made a major impact upon the development of traditional arts in Ganjuran. Many experts or students have been making researches on Ganjuran. There are some artists who are driven to create the artwork associated with Ganjuran. It is no less important is the establishment of an organization of traditional arts, such as gamelan (classical Javanese orchestra) and macapat (high Javanese philosophical poetry that recited in Javanese classical song form), gejog lesung (pealing paddy traditionally and rhythmically), traditional dance, and terbangan (singing with tambourine).

Besides the establishment of the traditional art organization, there was also an establishment of Management Committee of Pilgrimage Site (Panitia Pengelola Tempat Ziarah) in 2008. According to Sarjimin, chief manager of the committee, with the establishment of this committee, the whole activities are reorganized. Several large committees are formed, nurtured and facilitated to produce a variety of activities that really target and touched the lives of many people. The committee is in charge of rearranging all activities relating to the temple of Ganjuran including managing traditional art organization (Sarjimin, 29-06-2015).

In connection to the activities, in 2015 the Council published some basic guidelines for financial, called the Guidelines of Management Social Fund. In the Guidelines, it is written that $60 \%$ of any funds which are received from the activities related to the temple, such as offering, proceeds from the sale of worship books, and acceptance of parking, will be donated to the poor (Pedoman Pengelolaan Dana Sosial Paroki Hati Kudus Tuhan Yesus Ganjuran, 2015: 11).

In the analysis of the art world, it is seen that Father Tomo has established a routine collaboration that makes Ganjuran temple as a center of the art world. He acts as patron who is master of Javanese culture and agriculture because he graduated from agricultural school in the USA. He is also highborn. Based on that, he manages to build an art world in the Javanese nuance called the Sacred Heart of Jesus Site and put the temple as its center. 


\section{CONCLUSION}

In 1930, the Schmutzers succeeded in bringing Christianity in the Javanese culture by making the Catholic's place of worship in the shape of a Hindu temple but they didn't succeed to bring Catholics to pray in front of the temple. The Temple of Ganjuran then had been forgotten for sixty years because Catholics in Java are already familiar with the western culture so that the shape of a Hindu temple was considered unsuitable as a place of worship for Catholics. In 1988, Father Tomo didn't just bring Christianity in the Javanese culture but introduced to Catholics how to be Christian in the Javanese nuance. He said that the more we become Catholic the more we become Java. The temple of Ganjuran was 'born again' because of this concept.

As patrons, each had distinct roles that can be explained in terms of upstream and downstream frameworks. In initiating the Ganjuran temple, the Schmutzers role was more in the upstream, while the later neglect of the temple can be understood as the absence of their patronage from the downstream framework point of view. On the other hand, Father Tomo's role can be understood from both the upstream and downstream frameworks.

From the upstream framework, the data shows how Father Tomo has transformed a once personal worship object into a publicly accepted site of pilgrimage in the form of a complex of buildings called "Mandala Hati Kudus Yesus" (Site of the Sacred Heart of Jesus), which consists of the Ganjuran Parish Church, a pendapa ${ }^{4}$ for the pilgrims, a healing fountain, a healing bathing place, and a garden. From the downstream framework, the data has shown that he then created an insitution that acts as a patron which mantains and develops the site as an Art World.

\section{REFERENCES}

Aritonang, J.H. and Steenbrink, K., (Ed.). ( 2008), “ A History of Christianity in Indonesia", Leiden - Boston: Brill.

Becker, New Direction in the Sociology of Art.( 2003).

Becker, H.S. ( 2008), "Art World", University of California Press.

Dewan Paroki Ganjuran, Rahmat yang Menjadi Berkat. ( 2004)

Elihami, L.E. (1995), “Sejarah Berdirinya Paroki Hati Kudus Yesus Ganjuran: Inkulturasi Sebagai Landasan Tumbuh Dan Berkembangnya Paroki Hati Kudus Yesus Ganjuran Yogyakarta", Yogyakarta: Skripsi Universitas Sanata Dharma.

Helling, SJ, J. (1930), "Java aan het H. Hart van Jezus", dalam majalah St.Claverbond Magazine, vol 42. (trans: Galuh Ambar Sasi).

Pedoman Pengelolaan Dana Sosial Paroki Hati Kudus Tuhan Yesus Ganjuran. (2015).

Russel, Bertrand. ( 2004), History of Western Philosophy. First published in RoutledgeClassics, Routledge 11 New Fetter Lane, London.

Soekiman, Djoko. (2000), Kebudayaan Indis, Bentang, Yogyakarta.

Sulistyo, Bambang. (1995), "Pemogokan Buruh, Sebuah Kajian Sejarah", Yogya: Tiara Wacana.

Sumintardja, D. (1981), “Kompendium Sejarah Arsitektur jilid I",Bandung:Yayasan Penyelidikian Masalah Bangunan.

Teiseran, Martin.( 2013), Hati Yesus yang Manis, Jadikanlah Kasih-Mu KasihKu, Kanisius, Yogyakarta 


\section{ONLINE RESOURCES}

http://sejarahapp.blogspot.com/3 sept. 2015, h. 12.43

http://green-organic- rice.blogspot.com/2008/08/ sekretariat pelayanan tani dan nelayan, 25 June 2015, 16:39

kebudayaanindonesia.net, 06-02-2016

Interviews

Indra, 08-5-2015

Hendri, 08-5-2015

Astokodatu, 13-05-2015

Sarjimin, 29-06-2015 